\title{
ANALISIS KANDUNGAN NITROGEN (N) DAN POSFORUS (P) PADA LIMBAH JEROAN IKAN MUJAIR (Oreochromis mosambicus) DANAU LINDU
}

\author{
Analysis of Nitrogen (N) and Phosporous (P) of Offal Waste of Mujair Fish (Oreochromis \\ mosambicus) Lindu Lake
}

\author{
*Hildawianti, Vanny M. A. Tiwow, dan Paulus H. Abram \\ Pendidikan Kimia/FKIP - Universitas Tadulako, Palu - Indonesia 94118 \\ Received 02 June 2017, Revised 05 July 2017, Accepted 03 August 2017
}

\begin{abstract}
Effort to minimize the environmental pollution is using that waste as a base material of organic fertilizer. This study was conducted to determine the levels of Nitrogen $(N)$ and phosphorous $(P)$ contained in the offal waste of mujair fish (Oreochromis mosambicus) from Lindu lake. Samples of mujair offal waste were taken from fish saler on the street Towna, Palu. Analysis of Nitrogen levels usedKjeldhal method which consists of three phases, namely destruction, distillation and titration. On the other hand, for Phosphorus analysis was using wet digestion method, followed by absorbance measurements of samples with spectronic 20 at a wavelength of $720 \mathrm{~nm}$. Based on the analysis, the average of nitrogen $(N)$ levels in mujair offal wastewas $2.78 \%$, while the average of phosphorus $(P)$ levels was $2.48 \%$. From these results, it is known that mujair offal waste contains more nitrogen (N) compared to phosphorous (P). In addition, when compared to the quality standard liquid organic fertilizer $N$ and $P$ content in mujair offal almost meets the quality standard liquid fertilizer, where the minimum technical requirements of organic liquid fertilizer should contain a total $N$ content of $3-6 \%$ and $3-6 \% P_{2} O_{5}$.
\end{abstract}

Keywords: Offal mujair fish, kjedahl method, destruction, nitrogen, phosphorus

\section{Pendahuluan}

Danau Lindu yang ada di Sulawesi Tengah merupakan salah satu sumberdaya perairan yang potensial dikembangkan untuk memenuhi kebutuhan protein dan meningkatkan pendapatan bagi masyarakat Lindu. Penduduk di sekitar danau Lindu selain berkebun dan berladang, menggantungkan hidupnya di danau ini sebagai nelayan. Sekitar tiga ratus orang nelayanyang mencari ikan di danau tersebut (Baedah, 2010). Danau Lindu merupakan danau yang berpotensi untuk budidaya ikan air tawar, seperti mujair, nila, dan mas. Umumnya warga yang bermukim di sekitar danau Lindu hanya menangkap/membudidayakan ikan mujair.

Ikan mujair di kota Palu banyak diperdagangkan di pasar-pasar tradisional ataupun pinggir jalan. Ketika melakukan proses jual beli, ikan mujair tersebut langsung di bersihkan dari sisik, sirip maupun isi perut (jeroan) ikan tersebut. Limbah ikan ini umumnya hanya di buang sebagai limbah domestik dan di biarkan berserakan serta membusuk begitu saja. Sehingga dampak yang ditimbulkan dari limbah ikan yang terbuang ini dapat mengakibatkan pencemaran lingkungan dan udara, selain itu bau busuk yang ditimbulkan juga akan mengganggu saluran pernapasan. Jika tidak ditanggulangi dengan baik, maka limbah tersebut akan berdampak negatif bagi lingkungan. Keadaan itu juga terjadi pada limbah industri perikanan (Putri, 2010).

Bagian ikan yang termasuk limbah ikan adalah jeroan ikan. Jeroan ikan adalah bagian-bagian yang

*Correspondence

Hildawianti

Program Studi Pendidikan Kimia, Fakultas Keguruan dan IImu

Pendidikan, Universitas Tadulako

e-mail: hildaaf2412@gmail.com

Published by Universitas Tadulako 2017 terdapat didalam ikan. Pada bagian jeroan ini, terdiri dari berbagai organ misalnya lambung dan hati. Jeroan ikan yang terdiri dari berbagai organ akan terlihat ketika ikan tersebut dibersihkan (disiangi). (Hadiwiyoto, 1993)menyatakan bahwa organ-organ yang terlihat saat ikan disiangi adalah bladder (kandung kemih), ginjal, perut besar, usus buntu, empedu, dan instestine (usus halus).

Saat pengolahan ikan, jeroan ikan merupakan salah satu bagian ikan yang tidak digunakan atau dibuang begitu saja sama seperti sisik dan sirip ikan. Sehingga, jika limbah ini tidak dimanfaatkan maka akan dapat mencemari lingkungan. (Bhaskar \& Mahendrakar, 2008)menyatakan bahwa limbah industri perikanan misalnya jeroan memiliki kandungan protein dan lemak tak jenuh yang tinggi.Sedangkan menurut (Nurhayati, dkk., 2013) kandungan protein dalam jeroan ikan sturgeon (Acipenser persicus) $15,48 \%$, ikan catla (Catla catla) $8,52 \%$ dan ikan tongkol $16,72 \%$.

Pupuk berbahan baku ikan kaya akan unsur makro dan mikro. Pupuk tersebut dilaporkan nyata meningkatkan pertumbuhan beberapa jenis sayuran dengan tingkat penambahan hasil mencapai $60 \%$ dari perlakuan kontrol. Namun demikian, ikan yang digunakan dalam membuat puput organik berasal dari ikan yang berkualitas baik sehingga bersaing dengan kebutuhan masyarakat. Di sisi lain limbah ikan yang tersedia banyak yang tidak termanfaatkan (Lestari, dkk., 2011). Limbah ikan yang tidak termanfaatkan inilah yang dapat menyebabkan pencemaran lingkungan. Limbah ikan dalam bentuk padat seperti sisa-sisa potongan ikan yang digunakan sebagai pupuk organik mengandung sembilan persen nitrogen, tiga persen posforus dan enam persen kalsium. Selain itu, pemberian limbah ikan berupa sisa-sisa ikan asin yang dihaluskan memberikan 
pengaruh yang sangat nyata terhadap pertumbuhan dan hasil bawang putih (Siregar, 2003)

Tulisan ini dimaksudkan untuk mengetahui kandungan nitrogen $(\mathrm{N})$ dan posforus $(\mathrm{P})$ pada limbah jeroan ikan mujair (Oreochromis mosambicus) yang berasal dari danau Lindu.

\section{Metode}

\section{Alat dan Bahan}

Alat yang digunakan adalah: wadah sampel, pipet tetes, neraca digital, cawan penguap, spatulla, batang pengaduk, buret, statif dan klem, oven, labu Kjeldhal, alat destilasi, labu Erlenmeyer, cawan petri, aluminium foil, gelas ukur, gelas ukur, gelas ukur, labu ukur, labu ukur, labu ukur, kuvet dan Spektronik-20.

Bahan yang digunakan adalah aquades, larutan $\mathrm{H}_{2} \mathrm{SO}_{4}$ pekat $(K G a A)$, larutan $\mathrm{NaOH} 40 \%(K G a A)$, tablet Kjeldhal, indikator brom cresol green (bcg) (EMerck), indikator metil merah (mm) (E-Merck), larutan $\mathrm{H}_{3} \mathrm{BO}_{3} \quad 1 \%(K G a A)$, larutan $\mathrm{HCl} \quad 0,1 \quad \mathrm{~N}$ $(\mathrm{KGaA})$, larutan $\mathrm{HNO}_{3} 65 \%(K G a A)$, larutan $\mathrm{HClO}_{4} 65 \%(\mathrm{KGaA})$, serbuk ammonium molibdat $\left(\mathrm{NH}_{4} \mathrm{Mo}_{7} \mathrm{O}_{24} \cdot 4 \mathrm{H}_{2} \mathrm{O}\right)($ E-Merck), serbuk kalium anti monil tartrat $\left(\mathrm{K}(\mathrm{SbO}) \mathrm{C}_{4} \mathrm{H}_{4} \mathrm{O}_{6} \cdot 0,5 \mathrm{H}_{2} \mathrm{O}\right)(K G a A)$ dan asam askorbat $\left(\mathrm{C}_{6} \mathrm{H}_{8} \mathrm{O}_{6}\right)(K G a A)$.

\section{Preparasi sampel}

Sampel dipisahkan dari sisik dan sirip yang masih menyatu dengan sampel jeroan ikan mujair, kemudian diletakan pada cawan penguap lalu dipanaskan.

\section{Pembuatan larutan pereaksi pembangkit warna $P$}

Dua pereaksi pembangkit warna digunakan, yaitu pereaksi pekat dan pereaksi encer. 6 gram $\left(\mathrm{NH}_{4}\right)_{6} \mathrm{Mo}_{7} \mathrm{O}_{24} \cdot 4 \mathrm{H}_{2} \mathrm{O}$ dan 0,1135 gram $\mathrm{K}(\mathrm{SbO}) \mathrm{C}_{4} \mathrm{H}_{4} \mathrm{O}_{6} \cdot 0,5 \mathrm{H}_{2} \mathrm{O}$ direaksikan bersama, kemudianditambahkan $70 \mathrm{~mL} \mathrm{H}_{2} \mathrm{SO}_{4}$ pekat, lalu diencerkan dengan aquades hingga $500 \mathrm{~mL}$ untuk pereaksi pekat. Sedangkan pereaksi encer dibuat dengan melarutkan 0,256 gram asam askorbat dan ditambahkan dengan $25 \mathrm{~mL}$ pereaksi pekat kemudian diencerkansampai $250 \mathrm{~mL}$ dengan aquades.

\section{Pembuatan larutan asam borat $\left(\mathrm{H}_{3} \mathrm{BO}_{3}\right) 1 \%$}

10 gram serbuk $\mathrm{H}_{3} \mathrm{BO}_{3}$ dilarutkan dalam 1000 $\mathrm{mL}$ aquades.

\section{Pembuatan larutan natrium hidroksida ( $\mathrm{NaOH}$ ) $40 \%$}

40 gram serbuk $\mathrm{NaOH}$ dimasukkan dalam gelas kimia dan dilarutkan dengan menggunakan aquades sebanyak $60 \mathrm{~mL}$. Kemudian larutan tersebut didinginkan, setelah itu dimasukkan dalam labu ukur $100 \mathrm{~mL}$ dan diencerkan dengan aquades sampai tanda batas.

\section{Pembuatan indikator campuran (bcg dan $\mathrm{mm}$ )}

0,033 gram serbuk bromcresol green dicampur dengan serbuk metil merahsebanyak 0,0165 gram kemudian dilarutkan dengan etanol sebanyak $50 \mathrm{~mL}$.

\section{Penentuan kadar air}

Penentuan kadar air dibuat dengan metode oven pengering. Sampel jeroan ikan mujair dimasukkan sebanyak 100 gramke dalam oven dan dipanaskan dengan suhu $105{ }^{\circ} \mathrm{C}$ selama 9 jam. Kemudian didinginkan dalam desikator selama 15 menit, lalu ditimbang kembali. Kadar air ditentukan dengan rumus sebagai berikut (Sudarmaji, dkk., 1989):

$$
\text { Kadar Air (\%) }=\frac{\text { Berat awal-berat akhir }}{\text { Berat awal }} \times 100
$$

Untuk faktor koreksi (fk) menggunakan rumus (Sulaeman, dkk., 2005):

Faktor koreksi $(\mathrm{fk})=100 /(100-\%$ kadar air $)$

\section{Analisis nitrogen}

0,250 gram sampel dimasukkan ke dalam labu Kjeldhal $250 \mathrm{~mL}$ dan menambahkan 1 buah tablet Kjeldhal dan larutan $\mathrm{H}_{2} \mathrm{SO}_{4}$ pekat sebanyak 10 mL.Larutan didestruksi selama \pm 3 jam pada suhu $150{ }^{\circ} \mathrm{C}$ hingga suhu maksimum $350{ }^{\circ} \mathrm{C}$ dan diperoleh cairan jernih berwarna hijau. Hasil destruksi diencerkan dengan aquades sebanyak $50 \mathrm{ml}$. Kemudian larutan dikocok hingga homogen dan dibiarkan semalaman agar partikel mengendap. $10 \mathrm{~mL}$ larutan ekstrak sampel dimasukkan ke dalam labu didih $250 \mathrm{~mL}$ dan dimasukkan sedikit batu didih dan aquades hingga larutan mencapai setengah volume labu didih.b10 mL larutan $\mathrm{NaOH} 40 \%$ ditambahkan ke dalam labu didih yang berisi sampel. Kemudian, $10 \mathrm{~mL}$ asam borat $1 \%$ dimasukkan ke dalam erlenmeyer $100 \mathrm{~mL}$ dan ditambahkan 3 tetes indikator campuran (bcg dan $\mathrm{mm}$ ) yang digunakan sebagai penampung destilat kemudian dihubungkan dengan alat destilasi.Larutan didestilasi hingga volume penampung destilat mencapai $75 \mathrm{~mL}$ (berwarna hijau). Destilat yang dihasilkan kemudian dititrasi dengan $\mathrm{HCl} 0,1 \mathrm{~N}$ hingga larutan berwarna merah muda. Kadar nitrogen dihitung dengan menggunakan rumus sebagai berikut (Sulaeman,dkk., 2005):

$$
\% \mathrm{~N}=\frac{(\mathrm{ts}-\mathrm{tb}) \times \text { Normalitas } \mathrm{HCl} \times \mathrm{Ar} \mathrm{N} \times \mathrm{fk} \times 100}{\mathrm{mg} \mathrm{sampel}}
$$

\section{Analisis posforus}

\section{Preparasi sampel}

$0,500 \mathrm{~g}$ sampel berbentuk granula dimasukkan ke dalam cawan penguap, kemudian ditambahkan $5 \mathrm{~mL}$ larutan $\mathrm{HNO}_{3} 60 \%$ dan $0,5 \mathrm{~mL}$ larutan $\mathrm{HClO}_{4} 65$ $\%$ dan larutan tersebut dimasukkan ke dalam erlenmeyer dan dikocok, serta dibiarkan selama 1 malam.Setelah itu, larutan didestruksi dan destruksi diakhiri bila sudah keluar uap putihdan cairan dalam labu tersisa sekitar $0,5 \mathrm{~mL}$. Kemudianlarutan tersebut didinginkan dan diencerkandengan aquades sampai volume menjadi $50 \mathrm{~mL}$, lalu larutan dikocokhingga homogen dan setelah itu dibiarkan hingga 1 malam agar didapat ekstrak jernih. Larutan ini disebut sebagai ekstrak A (Eviati \& Sulaeman, 2009) 


\section{Pembuatan larutan deret standar $P$}

Larutan deret standar posforus dari larutan standar P 50 ppm dibuat variasi $0,2,4,6,8$ dan 10 ppm.Sebanyak 0, 2, 4, 6, 8 dan $10 \mathrm{~mL}$ larutan standar 50 ppm dimasukkan ke dalam masing-masing labu ukur $50 \mathrm{~mL}$ dan ditambahkan aquades sampai tanda batas (Eviati \& Sulaeman, 2009)

\section{Penentuan panjang gelombang maksimal}

$1 \mathrm{~mL}$ larutan standar posforus $50 \mathrm{ppm}$ dimasukkan ke dalam labu ukur $10 \mathrm{~mL}$. Kemudian ditambahkan larutan pereaksi $9 \mathrm{~mL}$, lalu didiamkan selama 15 menit.Setelah itu, larutan dimasukkankedalam kuvet dan absorbansi diukur pada panjang gelombang antara 580-750 nm.

\section{Penentuan kadar P pada sampel}

$1 \mathrm{~mL}$ ekstrak A dimasukkan ke dalam labu ukur $25 \mathrm{~mL}$, kemudian diencerkan dengan menggunakan aquades sampai tanda batas (ekstrak B). 1 mL ekstrak B dimasukkan ke dalam labu ukur $25 \mathrm{~mL}$, kemudian ditambahkan pereaksi pembangkit warna sebanyak 9 $\mathrm{mL}$ dan larutan dikocok hingga homogen. Larutan dibiarkan selama 15 menit, lalu dimasukkan ke dalam kuvet dan absorbansi larutan diukur dengan menggunakan spektronik-20 pada panjang gelombang maksimum. Kadar posforus di hitung dengan menggunakan rumus (Eviati \& Sulaeman, 2009):

Kadar P (\%) = ppm kurva $\mathrm{x} \mathrm{ml} \mathrm{ekstrak/1000} \mathrm{ml} \mathrm{x}$ 100/mg sampel x fp x 31/95 x fk

\section{Hasil dan Pembahasan}

\section{Analisis kadar air}

Analisis kadar air dalam sampel limbah jeroan ikan mujair dipaparkan dalam tabel 1 .

Tabel 1. Hasil analisis kadar air dalam sampel limbah jeroan ikan mujair (Oreochromis mosambicus)

\begin{tabular}{cccc}
\hline No & $\begin{array}{c}\text { Massa sampel } \\
\text { awal (g) }\end{array}$ & $\begin{array}{c}\text { Massa } \\
\text { sampel } \\
\text { akhir (g) }\end{array}$ & $\begin{array}{c}\text { Kadar air } \\
(\%)\end{array}$ \\
\hline 1 & 100 & 20,10 & 79,9 \\
2 & 100 & 21,00 & 79,0 \\
3 & 100 & 20,80 & 79,2 \\
\hline
\end{tabular}

Analisa ini dilakukan sebanyak 3 kali dan diperoleh hasil berturut-turut yaitu 79,9\%; 79\% dan 79,2\%. Setelah dirata-ratakan maka diperoleh persentase kadar air jeroan ikan mujair per 100 gram yaitu 79,3\%. Kadar air yang telah diperoleh digunakan untuk menghitung faktor koreksi, dimana faktor koreksi yang diperoleh yaitu 4,83. Faktor koreksi yang diperoleh digunakan untuk menghitung persentase kandungan nitrogen $(\mathrm{N})$ dan fosporus $(\mathrm{P})$ pada sampel. Air di dalam bahan pangan ada dalam tiga bentuk, yaitu air bebas, air terikat lemah atau air teradsorbsi dan air terikat kuat. Pada pengukuran kadar air bahan pangan, air yang terukur adalah air bebas dan air teradsorbsi. Jadi, kadar air suatu bahan pangan merupakan gabungan dari air bebas dan air teradsorbsi di dalam bahan tersebut(Legowo, dkk., 2007)

Metode analisis kadar air pada sampel ada beberapa jenis, diantaranya adalah metode pengeringan/oven, metode destilasi dan metode kimiawi. Pada penelitian ini, analisis kadar air menggunakan metode pengeringan. Metode pengeringan ini menggunakan oven, dimana sampel sebanyak 100 gram dimasukkan dalam oven dan dipanaskan pada suhu $105^{\circ} \mathrm{C}$ selama 9 jam. Setelah itu, sampel kemudian didinginkan dalam desikator selama 15 menit. Sampel yang telah dingin, lalu ditimbang kembali dengan menggunakan neraca digital, kemudian menghitung persentase kadar air. Metode pengeringan dengan oven didasarkan atas prinsip perhitungan selisih bobot bahan (sampel) sebelum dan sesudah pengeringan. Selisih bobot tersebut merupakan air yang teruapkan dan dihitung sebagai kadar air bahan (Legowo, dkk., 2007)

\section{Analisis kadar nitrogen (N)}

Analisis konsentrasi nitrogen pada sampel ikan mujair (Oreochromis mosambicus) menggunakan metode Kjeldahl. Metode ini terdiri dari 3 tahapan yaitu destruksi, destilasi dan titrasi. Prinsip metode Kjeldhal adalah penetapan jumlah protein secara empiris berdasarkan jumlah $\mathrm{N}$ didalam bahan. Setelah bahan dioksidasi, amonia (hasil konversi senyawa $N$ ) bereaksi dengan asam menjadi amonium sulfat. Dalam kondisi basa, amonia diuapkan dan kemudian ditangkap dengan larutan asam. Jumlah $\mathrm{N}$ ditentukan dengan titrasi $\mathrm{HCl}$ atau $\mathrm{NaOH}$ (Legowo \& Nurwantoro, 2004)

Asam sulfat $\left(\mathrm{H}_{2} \mathrm{SO}_{4}\right)$ pekat merupakan salah satu karakteristik asam pendestruksi yang sering digunakan dan dapat mempercepat terjadinya oksidasi meskipun waktu yang diperlukan untuk mendestruksi masih cukup lama (Kristianingrum, 2012). Dalam proses destruksi nitrogen akan terlepas dari protein sehingga pada akhir destruksi akan diperoleh $\left(\mathrm{NH}_{4}\right)_{2} \mathrm{SO}_{4}$, dimana hal ini didapatkan dari pemanasan $\mathrm{H}_{2} \mathrm{SO}_{4}$ pekat yang unsur $\mathrm{C}$ dan $\mathrm{H}$ teroksidasi menjadi $\mathrm{H}_{2} \mathrm{O}, \mathrm{CO}_{2}, \mathrm{CO}$ dan $\mathrm{N}$ berubah menjadi $\left(\mathrm{NH}_{4}\right)_{2} \mathrm{SO}_{4}$ (Legowo, 2005). Sedangkan tahap destilasi bertujuan untuk mengubah $\left(\mathrm{NH}_{4}\right)_{2} \mathrm{SO}_{4}$ yang diperoleh pada proses destruksi menjadi amonia $\left(\mathrm{NH}_{3}\right)$ melaui proses pemanasan dengan alat destilasi dan penambahan $\mathrm{NaOH}$. Pada proses destilasi, penampung destilat yang digunakan adalah larutan asam borat $\left(\mathrm{H}_{3} \mathrm{BO}_{3}\right) \quad 1 \%$ yang ditambahkan indikator campuran antara brom kresol green dan metil merah sebanyak 3 tetes. Larutan $\mathrm{H}_{3} \mathrm{BO}_{3}$ berfungsi sebagai penangkap $\mathrm{NH}_{3}$ yang merupakan destilat berupa gas yang bersifat basa. Sedangkan indikator berfungsi untuk mengetahui asam dalam keadaan yang berlebih.

Setelah proses destilasi, tahap selanjutnya adalah titrasi Pada tahap ini, jumlah asam borat yang bereaksi dengan $\mathrm{NH}_{3}$ dititrasi dengan $\mathrm{HCl} 0,1 \mathrm{~N}$. (Legowo \& Nurwantoro, 2004) menyatakan apabila digunakan $\mathrm{HCl}$ (sebagai penampung destilat), maka sisa $\mathrm{HCl}$ yang tidak bereaksi dengan $\mathrm{NH}_{3}$ ditirasi dengan $\mathrm{NaOH} 0,1 \mathrm{~N}$. Tetapi apabila penampung 
destilat merupakan asam borat, maka asam borat dititrasi dengan $\mathrm{HCl}(0,02-0,1 \mathrm{~N})$ Hasil analisis $\mathrm{N}$ pada jeroan ikan dapat dilihat pada Tabel 2.

Tabel 2. Hasil analisis nitrogen $(\mathrm{N})$ dalam sampel limbah jeroan ikan mujair

\begin{tabular}{cccccc}
\multicolumn{6}{c}{ limbah jeroan ikan mujair } \\
No & $\begin{array}{c}\text { Pengulangan } \\
\text { sampel }\end{array}$ & $\begin{array}{c}\text { Berat } \\
\text { Sampel } \\
(\mathbf{m g})\end{array}$ & $\begin{array}{c}\text { V. } \\
\text { titrasi } \\
\text { blanko } \\
(\mathbf{m l})\end{array}$ & $\begin{array}{c}\text { V. } \\
\text { titrasi } \\
\text { sampel } \\
(\mathbf{m l})\end{array}$ & $\begin{array}{c}\text { Kadar } \\
\text { N (\%) }\end{array}$ \\
\hline 1 & I & 250 & 0,5 & 1,6 & 2,97 \\
2 & II & 250 & 0,5 & 1,5 & 2,70 \\
3 & III & 250 & 0,5 & 1,6 & 2,97 \\
\hline
\end{tabular}

Nilai rata-rata setelah dianalisis sebanyak $3 \mathrm{kali}$, di peroleh kandungan nitrogen $(\mathrm{N})$ pada jeroan ikan mujair yaitu 2,88\%. jika dibandingkan dengan Peraturan Menteri Pertanian No.70/Permentan/SR.140/10/2011, kadar N ratarata yang diperoleh dari jeroan ikan mujair hampir memenuhi persyaratan teknis minimal pupuk cair organik dimana dalam peraturan menteri pertanian tersebut dinyatakan bahwa $\mathrm{N}$ total pada pupuk organik cair memiliki kadar N minimal 3-6\%. Pupuk yang berasal dari jeroan ikan adalah sumber nutrisi yang sangat baik untuk tanah dan tanaman. Pupuk ini cocok untuk semua tanaman buah-buahan, bunga dan sayuran, dimana pengaplikasiannya dapat diterapkan melalui daun atau tanah, karena mampu menyediakan nutrisi dan mineral yang diperlukan. Selain itu, pupuk jeroan ikan menyediakan banyak posforus dan hitrogen organik (Lema \& Degabassa, 2012)

Nitrogen yang terdapat pada tumbuhan dan hewan berupa bentuk protein yang komposisi rataratanya $51 \% \mathrm{C} ; 25 \% \mathrm{O} ; 16 \% \mathrm{~N} ; 7 \% \mathrm{H}, 0,4 \% \mathrm{P}$ dan $0,4 \%$ S. Nitrogen merupakan unsur hara utama bagi pertumbuhan tanaman, yang pada umumnya sangat diperlukan untuk pembentukan atau pertumbuhan bagian-bagian vegetatif tanaman, seperti daun, batang dan akar, tetapi kalau terlalu banyak dapat menghambat perkembangan dan pembuahan pada tanamannya. Fungsi nitrogen bagi tanaman yaitu untuk meningkatkan pertumbuhan tanaman, dapat menyehatkan pertumbuhan daun, dan tanaman lebar dengan warna yang lebih hijau (Affandi \& Tang, 2002)

\section{Analisis kadar posforus (P)}

Analisis kadar posforus (P) pada sampel jeroan ikan mujair menggunakan metode pengabuan basah dan dilanjutkan dengan metode spektrofotometri. Dalam tahap awal, sampel didestruksi dengan cara menambahkan 5 mL larutan $\mathrm{HNO}_{3} 60 \%$ dan $0,5 \mathrm{~mL}$ larutan $\mathrm{HClO}_{4}$ 65\%. Tahap selanjutnya yaitu membuat larutan standar posforus dimana larutan standar posforus ini dibuat dari larutan stok P 50 ppm. Larutan standar dibuat variasi yaitu $0 ; 2 ; 4 ; 6 ; 8$ dan $10 \mathrm{ppm}$. sedangkan untuk penentuan panjang gelombang maksimal digunakan larutan standar posforus sebanyak $1 \mathrm{~mL}$ yang kemudian ditambahkan dengan larutan pereaksi sebanyak $9 \mathrm{~mL}$. Setelah itu, didiamkan selama 15 menit dan kemudian di ukur absorbansinya dengan menggunakan spektronik 20 pada panjang gelombang 580-750. Dari hasil pengukuran diperoleh panjang gelombang maksimum yaitu pada panjang gelombang $720 \mathrm{~nm}$.

Larutan pereaksi yang digunakan adalah campuran larutan amonium molibdat $\left[\left(\mathrm{NH}_{4}\right)_{6} \mathrm{Mo}_{7} \mathrm{O}_{24} \cdot 4 \mathrm{H}_{2} \mathrm{O}\right]$, kalium antimonil tatrat, larutan $\mathrm{H}_{2} \mathrm{SO}_{4}$ dan asam askorbat. Kalium antimonil tatrat merupakan pereaksi pembangkit warna, dimana dengan intensitas warna yang baik maka pengukuran absorbansi lebih sensitif. Sedangkan asam askorbat merpakan agen pereduksi. Senyawa amonium molibdat dan kalium antimonil tatrat akan bereaksi dengan senyawa ortofosfat yang ada dalam jaringan (Amin \& Flowers, 2012)

Penambahan medium asam, asam ortofosfat membentuk kompleks berwarna kuning dengan molibdat. Dengan adanya asam askorbat dan antimoniltatrat maka terbentuklah kompleks molibdat yang berwarna biru. Moniltatrat ditambahkan untuk melengkapi reduksi kompleks fosfomolibdenum kuning menjadi kompleks fosfomolibdenum biru (Walinga, 1995). Prinsip dari analisis posforus menggunakan spektrofotometri sinar tampak adalah ion ortofosfat dengan molibdat dalam suasana asam akan membentuk phospomolibdat. Reduksi dengan asam askorbat akan membentuk senyawa berwarna dari molibdenum biru dan diukur absorbansinya pada panjang gelombang $700 \mathrm{~nm}$ (Walinga, 1989)

Selanjutnya yaitu pembuatan kurva kalibrasi. Kurva kalibrasi ini diperoleh dari pengukuran larutan standar posforus (0-10 $\mathrm{ppm})$ dengan menggunakan spetronik 20 pada panjang gelombang maksimum yaitu $720 \mathrm{~nm}$. Kurva kalibrasi yang dihasilkan dapat dilihat pada Gambar 1.

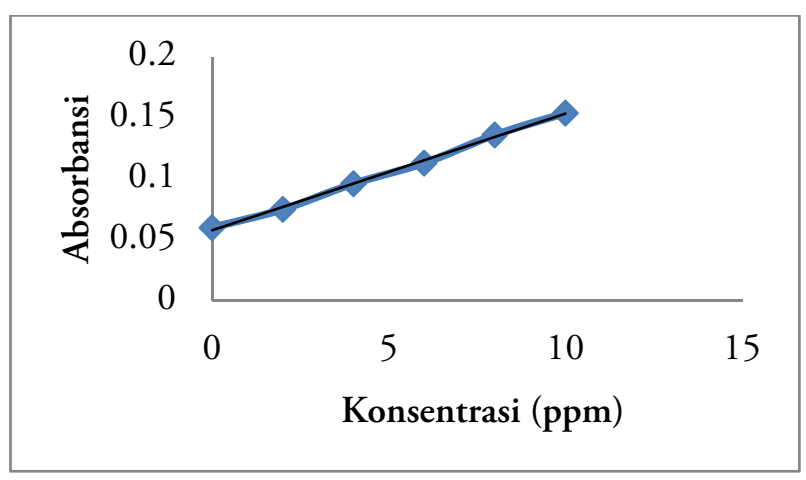

Gambar 1. Kurva Kalibrasi untuk posforus

Jika dilihat dari persamaan regresi diperoleh $\mathrm{y}=$ 0,0096 $+0,0578$. Persamaan regresi ini digunakan untuk mengetahui konsentrasi posforus pada sampel. Dalam penentuan kadar $\mathrm{P}$ ini, terlebih dahulu $1 \mathrm{~mL}$ ekstrak A diencerkan dengan aquades, kemudian larutan ini disebut sebagai ekstrak B. $1 \mathrm{~mL}$ dari ekstrak B kemudian ditambahkan dengan $9 \mathrm{~mL}$ larutan pereaksi dan setelah itu mengukur absorbansi dari larutan sampel tersebut. Pengukuran ini dilakukan sebanyak 3 kali, dimana masing-masing 
absorbansinya adalah 0,$214 ; 0,200$; dan 0,214 . Dari hasil absorbansi ini, konsentrasi sampel dapat diketahui dengan menggunakan persamaan regresi sehingga di peroleh konsentrasi masing-masing yaitu 16,27 ppm; 14,81 ppm; dan 16,27 ppm. Hasil yang di peroleh ini dinyatakan sebagai kurva ppm yang akan digunakan untuk mengetahui persentase kadar $\mathrm{P}$ dalam sampel. Hasil analisis kadar P pada jeroan ikan Mujair dapat dilihat pada Tabel 3.

Tabel 3. Hasil analisis posforus (P) dalam sampel limbah jeroan ikan mujair (Oreochromis mosambicus)

\begin{tabular}{llccc}
\hline No & $\begin{array}{c}\text { Pengulangan } \\
\text { sampel }\end{array}$ & $\% \mathrm{~T}$ & A & $\begin{array}{c}\text { Kadar P } \\
(\%)\end{array}$ \\
\hline 1 & I & 61 & 0,214 & 2,56 \\
2 & II & 63 & 0,200 & 2,33 \\
3 & III & 61 & 0,214 & 2,56 \\
\hline
\end{tabular}

Bila dibandingkan dengan Peraturan Menteri Pertanian No.70/Permentan/SR.140/10/2011, kadar $\mathrm{P}$ pada jeroan ikan juga hampir memenuhi persyaratan minimal untuk digunakan dalam pembuatan pupuk organik cair dimana pada Permentan tersebut kadar $\mathrm{P}$ dalam bentuk $\mathrm{P}_{2} \mathrm{O}_{5}$ adalah 3-6\%.

Kandungan mineral pada ikan tergantung pada spesies, jenis kelamin, siklus biologis, dan bagian tubuh ikan yang dianalisis. Kandungan mineral ikan juga tergantung pada faktor ekologis seperti musim, tempat pengembangan jumlah nutrisi yang tersedia, suhu dan salinitas air. Di dalam ekosistem air terjadi daur posforus. Fosfat yang terlarut didalam air diserap oleh ganggang dan tumbuhan air. Sedangkan ikanikan mendapatkan fosfat melalui rantai makanan (Ye, dkk., 2006).

\section{Kesimpulan}

Kadar nitrogen pada jeroan ikan mujair yang berasal dari danau Lindu adalah 2,88\%. Sedangkan kadar posforus pada jeroan ikan mujair Lindu adalah $2,48 \%$.

\section{Ucapan Terima Kasih}

Ucapan terima kasih penulis berikan kepada laboran Laboratorium Kimia Fakultas Keguruan dan Ilmu Pendidikan Universitas Tadulako, Palu, Sulawesi Tengah dan teman-teman yang banyak membantu penulis dalam menyelesaikan penelitian ini.

\section{Referensi}

Affandi, R., \& Tang, U. (2002). Fisiologi hewan air. Riau: University Riau Press.

Amin, M., \& Flowers, T. H. (2012). Evaluation of kjeldahl digestion method. Journal of Research (Science), Bahaudin Zakariya University, Multan, Pakistan, 15, 159-179.
Baedah, M. A. (2010). Mengelola danau lindu secara bijak. Sulawesi Tengah: Dinas Kelautan dan Perikanan.

Bhaskar, N., \& Mahendrakar, N. (2008). Protein hydrolisate from visceral waste protein of catla (Catla catla): optimization of hydrolysis condition for a commercial neutral protease. Journal Bioresource Technology, 99, 4105-4111.

Eviati, \& Sulaeman. (2009). Analisa kimia tanah, tanaman, air dan pupuk. Bogor: Badan Penelitian Dan Pengembangan Pertanian Departemen Pertanian.

Hadiwiyoto, S. (1993). Teknologi hasil perikanan. Yogyakarta: Liberty.

Kristianingrum, S. (2012). Kajian berbagai destruksi sampel dan efeknya. Yogyakarta: Makalah pada Seminar Nasional MIPA UNY.

Legowo, M. A. (2005). Diversifikasi produk olahan dengan bahan baku susu. Semarang: UNDIP Press.

Legowo, M. A., \& Nurwantoro. (2004). Analisis pangan. Semarang: UNDIP press.

Legowo, M. A., Nurwantoro, \& Sutaryo. (2007). Buku ajar analisis pangan. Semarang: UNDIP Press.

Lema, A., \& Degabassa, A. (2012). Comparisson of chemical fertilizer, fish offal's fertilizer and manure applied to tomato and onion. African Journal of Agricultural Research, 8(3), 274-278.

Lestari, I. P., Sastro, Y., \& Irawati, A. F. (2011). Kajian teknologi fermentasi limbah ikan sebagai pupuk organik. Jakarta: Balai Pengkajian Teknologi Pertanian.

Nurhayati, T., Desniar, \& Suhandana, M. (2013). Pembuatan pepton secara enzimatis menggunakan bahan baku jeroan ikan tongkol. Jurnal Pengolahan Hasil Perikanan Indonesia, 16(1), 1-11.

Putri, A. (2010). Strategi pengembangan industri kreatif berbasis limbah industri perikanan sebagai solusi mengatasi permasalahan ekonomi dan lingkungan indonesia. Karya Ilmiah IPB. Bogor.

Siregar, H. (2003). Pengaruh pemberian limbah cair tepung ikan terhadap pertumbuhan hasil cabai (capsicum annum.l) dan terung (solanum melongena l.). Skripsi. Bogor: Fakultas Pertanian Universitas Pertanian Bogor.

Sudarmaji, Haryono, H., \& Suhardi, B. (1989). Analisa bahan makanan dan pertanian. Yogyakarta: Liberti.

Sulaeman, Suparto, \& Eviati. (2005). Analisis kimia tanah, tanaman, air dan pupuk. Bogor: Badan 
Penelitian Dan Pengembangan Pertanian Departemen Pertanian.

Walinga, I. (1989). Plant analysis procedures. Nederlands: Waganingen Agricultural University.

Walinga, I. (1995). Plant analysis manual. Dordrecht: Kluwer Academic Publishers.
Ye, C. X., Liu, Y. J., Tian, L. X., Mai, K. S., Du, Z. Y., Yang, H., \& Niu, J. (2006). Effect of dietary calcium and phosphorus on growth, feed efficiency, mineral content and body composition of juvenil grouper, Epinephelus coioides. Aquaculture, 255,263-271. 